Ann. Biol. anim. Bioch. Biophys., 1979, 19 (4 B), 1307-1316

\title{
Testosterone levels in umbilical cord blood, maternal peripheral plasma and amniotic fluid of the crab-eating monkey (Macaca fascicularis)
}

\author{
par D. C. DANG, Nicole MEUSY-DESSOLLE * \\ Laboratoire d'Anatomie, UER Biomédicale, 45, rue des Saints-Pères, 75006 Paris \\ * Laboratoire de Physiologie de la Reproduction des Vertébrés, Université Paris VI, \\ and I. N. R. A., 78350 jouy en Josas, France.
}

\begin{abstract}
Summary. 88 crab-eating macaque (Macaca fascicularis) fetuses of known age were studied from day 37 of gestation until near term. Umbilical artery plasma testosterone (UAPT) and umbilical vein plasma testosterone (UVPT) as well as amniotic fluid testosterone (AFT) and maternal peripheral plasma testosterone were radioimmunologically assayed. (1) In 57-day male fetuses, UAPT level was 3 to $4 \mathrm{ng} / \mathrm{ml}$; it dropped to 0.5 to $1 \mathrm{ng} / \mathrm{ml}$ near 75 days and stayed at that level until term. This content in female fetuses remained at about $1 \mathrm{ng} / \mathrm{ml}$ throughout gestation (fig. 1). (2) During the second-half of gestation, UVPT content was generally lower than UAPT content, whatever the fetal sex (table 1). (3) AFT level was clearly lower than UAPT or UVPT level ; it stayed under the sensitivity limit of the assay method in most of the female fetuses. The AFT concentration curve in male fetuses was parallel to that of UAPT (fig. 2). The correlation coefficient $(r=0.71)$ (fig. 3), together with the relatively large quantities of AFT in 37 to 50-day male fetuses, suggested that the fetal testis could secrete testosterone at a very early stage when the Leydig cells were not yet recognizable. (4) There was no relation between maternal testosteronemia and the sex of the conceptus at any time during gestation (fig. 4).
\end{abstract}

\section{Introduction.}

Throughout the various critical stages of embryonic development, the sexual differentiation of organs and functions mainly depends on the sex hormones. It is therefore of prime importance to precisely define the steroid pattern arising from testicular activity during the course of embryonic development. Up to the present, the data obtained on the rhesus macaque, Macaca mulatia (Resko, 1974 ; Huhtaniemi ef al., 1979), have not determined the exact time at which androgens appear in the fetus.

Although ultrastructural studies of the embryonic testis of Macaca fascicularis showed steroidogenesis in the fetal Leydig cells (Fouquet, Dang and Meusy-Dessolle, 1978), the timing of androgen initiation was not determined and the chemical nature of the androgens remained unknown. The amount of Macaca fascicularis blood necessary for our radioimmunoassay (RIA) can be drained only from day 57 on of fetal life. 
At that age, androgens are already present in the plasma of $M$. mulatta (Resko et al., 1973). The only biological fluid available in a younger fetus is the amniotic fluid. We have thus tried to determine if there is any correlation between the testosterone content of amniotic fluid and that of the venous and arterial blood of the umbilical cord. If the two levels could be related, the amniotic fluid might signal fetal steroidogenesis, and its testosterone level would be valuable for screening that activity in the early testis (Dang and Fouquet, 1979) and up to 57 days.

The second part of this study attempted to determine if there is a relationship between testosterone level in the maternal peripheral blood and the sex of the fetus.

\section{Material and methods.}

The 88 fetuses used in this study were all delivered by cesarean section according to a method described previously by Dang (1977b). All interventions were carried out at the beginning of the afternoon. The day of parental meeting was day 0 of gestation. The male was usually put with the female for $24 \mathrm{hrs}$ (and rarely for $48 \mathrm{hrs}$ ), starting on day 12 of the menstrual cycle (Dang, 1977a). Depending on fetal age, three methods were used to sex the conceptus :

- up to 45 days : analysis of the sex chromatin of the amniotic membrane cells;

- 45 to 70 days : histological examination of the gonad;

- 70 days on : simple examination of the genitalia (Dang, 1978).

The ketamine + pentothal anesthesia we had previously practised on the mature and immature crab-eating monkey, $M$. fascicularis, had no effect on plasma testosterone levels, and it was assumed that this anesthesia would not affect fetal testis androgenic function either, if used to anesthetize the mothers for the cesarean.

Both plasma and amniotic fluid testosterone levels were assayed by a RIA method using a cyclohexane-ethyl acetate mixture for extraction without any chromatographic step. This technique resembled that used for the assay of plasma testosterone in pigs (Meusy-Dessolle, 1974, 1975). The antibody was raised in rabbits against the 3-0-carboxy-methyloxime testosterone coupled with bovine serum albumin (BSA) and saturated with BSA before use. Antibody specificity showed the following cross-reactions : 0.9 p. 100 with $\Delta_{4}$-androstenedione, 10.8 p. 100 with $3 \beta-5 \alpha$-androstanediol, and 28.4 p. 100 with dihydrotestosterone. Assay sensitivity was about $50 \mathrm{pg} / \mathrm{ml}$. The intraassay variabilities were 5.8 and 3.1 p. 100 for 1.5 and $11.4 \mathrm{ng} / \mathrm{ml}$ of plasma, respectively. The interassay coefficients of variation were 9.7 p. 100 for $1.5 \mathrm{ng} / \mathrm{ml}$ of plasma and 4.2 p. 100 for $11.8 \mathrm{ng} / \mathrm{ml}$ of plasma. Mean « water blank» was $0.012 \mathrm{ng} / \mathrm{ml}$. Mean recovery after extraction was $94 \pm 0.2$ p. 100.

\section{Results.}

Umbilical artery plasma testosterone (UAPT) and umbilical vein plasma testosterone (UVPT). - At day 57 of male development, UAPT content was already high $(3$ to $4 \mathrm{ng} / \mathrm{ml}$ fig. 1) and nearly at the peripheral vein plasma level of adult males during the light/dark cycle (Dang and Meusy-Dessolle, in press). That concentration dropped rapidly and, depending on the individual, reached a plateau between 0.5 and 
$1 \mathrm{ng} / \mathrm{ml}$ at around 75 days; it then remained constant until near term (table 1). On the contrary, female fetuses showed a mean UAPT concentration of about $0.3 \mathrm{ng} / \mathrm{ml}$ which varied little throughout gestation (fig. 1, table 1).

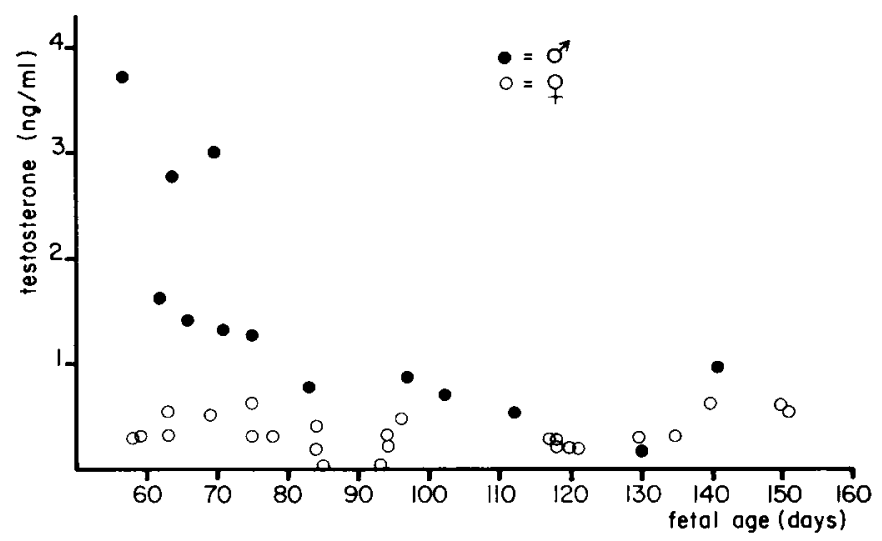

FIG. 1. - Plasma testosterone level in the umbilical artery according to fefol age.

TABLE 1

Individual testosterone levels in umbilical artery and vein plasma $(\mathrm{ng} / \mathrm{ml})$ during the second-half of gestation

Male fetus

\begin{tabular}{|c|c|c|c|c|c|}
\hline $\begin{array}{c}\text { Age } \\
\text { (days) }\end{array}$ & Artery & Vein & $\begin{array}{c}\text { Age } \\
\text { (days) }\end{array}$ & Artery & Vein \\
\hline $\begin{array}{l}75 \\
83\end{array}$ & $\begin{array}{l}1.26 \\
0.77\end{array}$ & $\begin{array}{l}0.38 \\
0.35\end{array}$ & $\begin{array}{l}78 \\
84 \\
84 \\
85 \\
93 \\
94 \\
94 \\
96\end{array}$ & $\begin{array}{r}0.29 \\
0.39 \\
0.17 \\
<0.05 \\
<0.05 \\
0.32 \\
0.20 \\
0.48\end{array}$ & $\begin{array}{r}<0.05 \\
0.25 \\
0.19 \\
<0.05 \\
<0.05 \\
<0.05 \\
0.06 \\
0.44\end{array}$ \\
\hline 102 & 0.68 & 0.33 & & & \\
\hline 112 & 0.53 & 0.33 & $\begin{array}{l}117 \\
118 \\
120 \\
121\end{array}$ & $\begin{array}{l}0.26 \\
0.24 \\
0.18 \\
0.19\end{array}$ & $\begin{array}{l}0.10 \\
0.12 \\
0.19 \\
0.31\end{array}$ \\
\hline 130 & 0.15 & 0.17 & $\begin{array}{l}130 \\
135\end{array}$ & $\begin{array}{l}0.27 \\
0.30\end{array}$ & \\
\hline 141 & 0.95 & 0.37 & $\begin{array}{l}140 \\
150 \\
151\end{array}$ & $\begin{array}{l}0.61 \\
0.58 \\
0.63\end{array}$ & $\begin{array}{r}<0.05 \\
0.54 \\
0.54\end{array}$ \\
\hline $\bar{x}$ & 0.72 & 0.32 & $\bar{x}$ & 0.30 & 0.18 \\
\hline$\stackrel{ \pm}{\mathrm{SE}}$ & $\stackrel{ \pm}{ \pm .15}$ & 0.03 & $\stackrel{ \pm}{S E}$ & $\frac{ \pm}{0.04}$ & $\frac{ \pm}{0.04}$ \\
\hline
\end{tabular}

Female fetus 
Due to the quick arrest of the venous circulation, it was nearly impossible to alternatively drain both the umbilical artery and the umbilical vein blood from the embryo before 75 days of age. Thus, comparative data on arterial and venous testosterone levels only concern older fetuses.

Table 1 shows that from 75 days until near term, UVPT concentration was generally lower than UAPT level in male fetuses and in female fetuses. The following results should also be retained :

- there was no significant difference between the UVPT/UAPT ratios in male and female fetuses $(0.56 \pm 0.12$ and $0.70 \pm 0.10$, respectively) ;

- the correlation coefficient between UVPT and UAPT levels was $r=0.89(P<0.02)$ for male fetuses and $r=0.61(P<0.01)$ for female fetuses. If $X=$ UVPT and $Y=U A P T$, the regressions are, respectively : $Y=4.33 X-0.67$ for male fetuses and $Y=0.58 X+0.02$ for females;

- the difference between arterial and venous testosterone levels in umbilical cord blood was greater in the males than in the females. It may be that the arterial blood of the male fetuses loses more testosterone in its placental migration than does the female blood.

Amniotic fluid testosterone (AFT). - Amniotic fluid testosterone (AFT) content was about one tenth of the UAPT content. Only 38 (42.7 p. 100) of the 88 amniotic fluid samples collected from various fetuses of different ages had a testosterone level higher than the sensitivity limit of our assay method (50 pg/ml) (fig. 3); 31 of these 38 samples came from male fetuses.

There was a sex difference in AFT concentration up to day 110 of gestation. In fact, between 37 and 110 days, 31 out of 40 male fetuses $(77.5$ p. 100) vs 5 out of 35 fe-

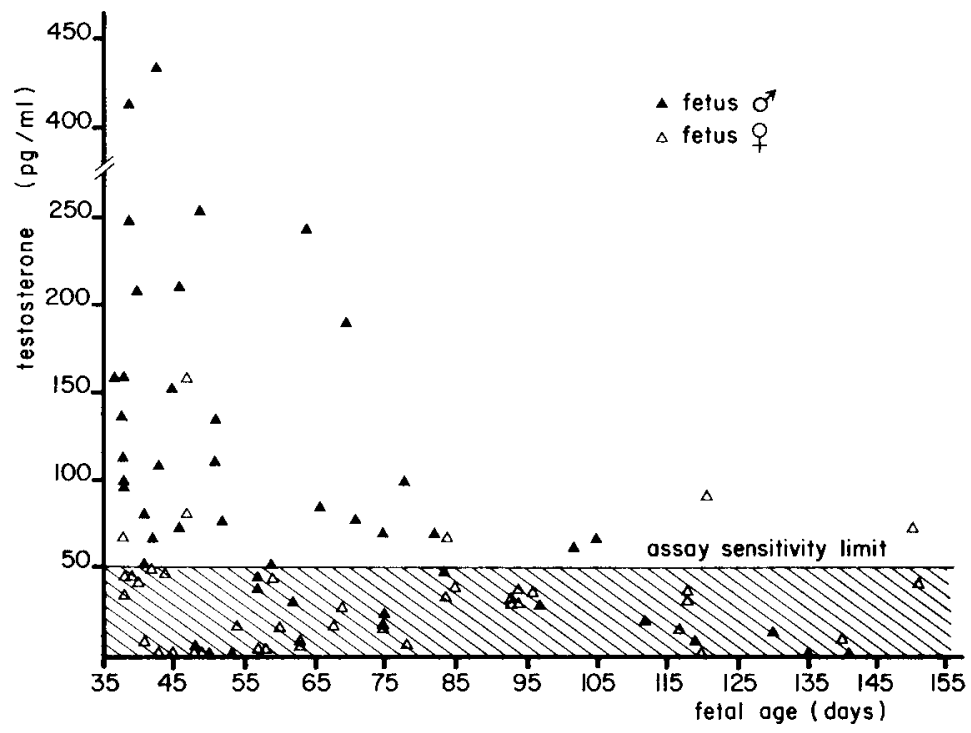

FIG. 2. - Testosterone concentration in the amniotic fluid during gestation. 
males (14.2 p. 100) showed a higher AFT level than our assay sensitivity limit. The $\chi^{2}$ analysis evidenced a highly significant difference $(P<0.001)$.

Only 2 out of 23 samples $(8.7$ p. 100), from fetuses older than 110 days, contained slightly more than $50 \mathrm{pg} / \mathrm{ml}$; oddly, they were both drained from females. Therefore, from day 110 of gestation on, the conceptus could not be sexed by its AFT level with our assay method. Moreover, AFT content did not vary much during gestation in female embryos, while its pattern was similar to that of the UAPT level in males (figs. 1, 2).

When only values above the sensitivity limit of our assay method (fig. 3) were considered, a positive correlation $(r=0.71 ; P \leqslant 0.02)$ was found between the levels of AFT and UAPT (fig. 3), whatever the fetal sex. This positive correlation, together with the impossibility of assaying UAPT content before day 57 of gestation, led to the conclusion that the high AFT levels in male fetuses before that time implied high testosteronemia at a very early stage. The origin of this androgenic activity is still unknown.

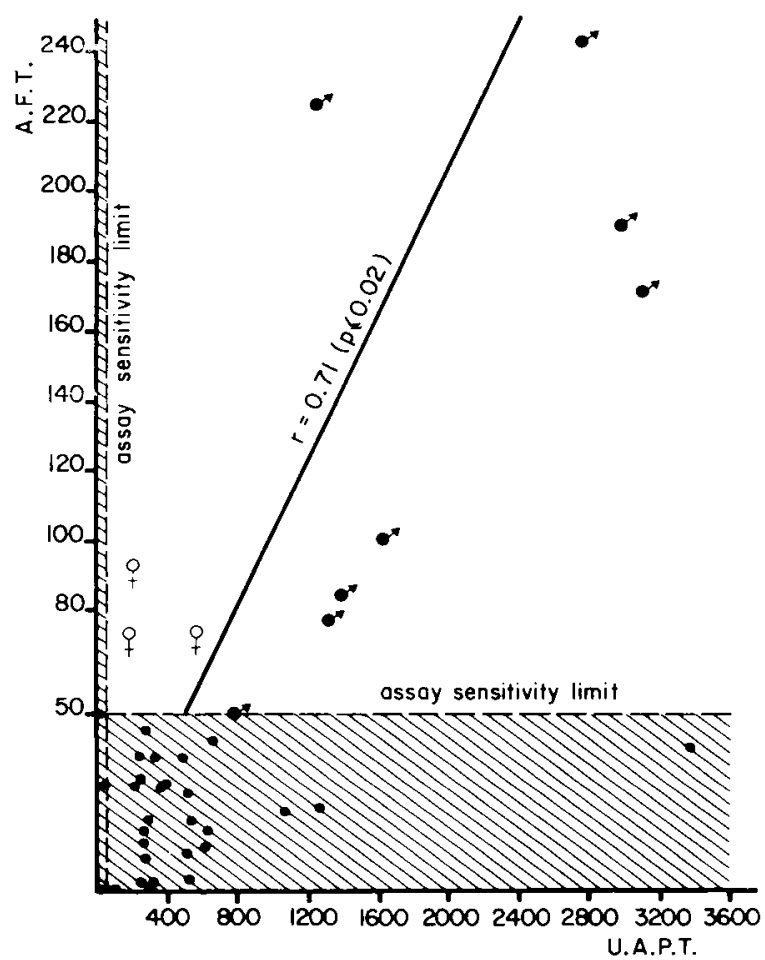

FIG. 3. - Correlation between testosterone levels in the amniotic fluid (AFT) and the umbilical artery blood (UAPT).

Maternal plasma testosterone. - The testosterone level of the brachial or saphenous vein blood of the mother was assayed throughout gestation, and showed no fetal sex difference, even between days 57 and 75 when fetal male blood testosteronemia 
was at a maximum (fig. 4). Thus, a difference between male and female UAPT patterns was not expressed in the maternal peripheral blood using our assay method.

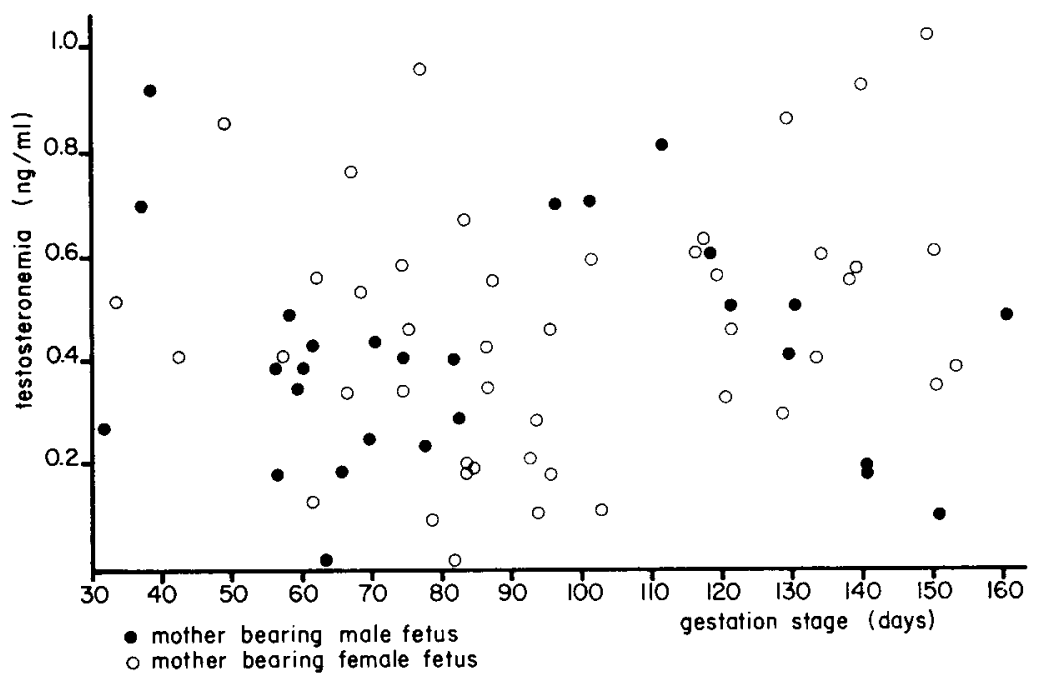

FIG. 4. - Testosterone in the maternal peripheral plasma during gestation.

\section{Discussion.}

Resko ef al. (1973) studying the M. mulatta fetus at more than 59 days, noted a sex difference in the umbilical arterial blood testosterone level with higher levels in the male fetus, which became evident at that developmental stage and lasted until near term. Those authors also reported that the UAPT was higher than the UVPT in male fetuses, but found no such difference in the females. Moreover, castration of the 100-day old male fetus was followed by a significant decrease of the circulating testosterone level in the umbilical artery; this was consistent with the testicular origin of testosterone overcontent in the male fetus. The testosterone concentrations we noted in $M$. fascicularis fetuses during gestation agree with those mentioned by Resko ef al. studying $M$. mulatta. Between days 57 and 75 of embryonic development, there was a marked sex difference in the UAPT content of crab-eating macaques, although this level varied widely among individual males. This period covers the phase of Leydig cell maturation (Fouquet, Dang and Meusy-Dessolle, 1978) during which the male genifalia also differentiate (Dang, 1978).

The difference between fetal male and female UAPT contents decreased from midgestation to birth (days 142 to 172 of gestation). It should be noted that the Leydig cells also began involution at about day 75 of gestation (Fouquet, Dang and MeusyDessolle, 1978).

We agree with Resko et al. (1973) that macaque male fetuses have a lower testosterone concentration in the umbilical vein blood than in the umbilical artery blood, but contrary to those authors, we also found this arterio-venous difference in female 
fetuses of $M$. fascicularis. It was greater in males than in females, but the UVPT/UAPT ratio was not significantly different in the fetal sexes. We cannot yet ascertain the exact role played by the placenta in respect to fetal blood testosterone level, but efferent blood from the placenta returns an amount of testosterone to the fetus which is directly proportional to the content of the umbilical artery blood (see correlation analysis). The small number of samples in this study did not permit us to determine whether or not there was a non-linear correlation between UAPT and UVPT contents.

The results obtained on AFT level in M. fascicularis showed that :

- RIA is possible;

- the AFT pattern corresponds to that of UAPT ;

- there is a positive correlation between these two levels, whatever the embryonic sex, but the small number of samples available prevented a study of possible nonlinear correlation.

Up to now, all the AFT data on humans reported by different laboratories are consistent with the present findings which are reported for the first time on another primate. UAPT in humans is higher in male fetuses before mid-gestation than in females; this difference then decreases and finally disappears around term (Mizuno et al., 1968 ; Rivarola, Forest and Migeon, 1968 ; Saez and Bertrand, 1969 ; Abramovich and Rowe, 1973 ; Reyes et al., 1974). AFT level progresses in the same way (Saez and Bertrand, 1969 ; Younglai, 1972 ; Younglai and Lin, 1973 ; Frasier, Weiss and Horton, 1974 ; Giles ef al., 1974 ; Judd et al., 1976 ; Belisle, Fencl and Tulchinsky, 1977 ; Robinson et al., 1977 ; Zondek, Mansfield and Zondek, 1977).

We have stressed the importance of assaying testosterone level in $M$. fascicularis amniotic fluid at a time when its plasma concentration cannot be measured with the methods presently available.

The correlation between UAPT and AFT contents indicates that fetal blood testosterone level is rather high before day 57 of gestation. This raises several questions.

1) Since M. fascicularis Leydig cells do not develop true steroidogenic features, visible by electron microscopic observation, until day 51 of fetal life (Fouquet, Dang and Meusy-Dessolle, 1978), is the testosterone found of testicular origin ? It is highly probable, for Resko (1970) reported in vitro experiments on rhesus macaque testes actually converting pregnenolone to testosterone at about 45 days, i. e. 10 days before any Leydig cells were observed, true Leydig cells in that species only being found from day 54 on (Van Wagenen and Simpson, 1965). If the ultrastructural characteristics of a steroidogenic cell express the cell adaptation to a high level of steroid synthesis, the absence of these same structures would not negate steroidogenesis which might still occur at a lower level.

Our interpretation of early fetal testis testosterone secretion may be compared to some observations on other mammals. In fetal sheep having a gestation time similar to macaques, testosterone and androstenedione were detected by gas-liquid chromatography (Attal, 1969) in a gonadal extract at 30 days, i. e. 5 days before gonadal differentiation. More recently, Mauléon, Bézard and Terqui (1977) reported that a very small amount of testosterone was secreted by testes of the same age kept in vitro, and that a very high level of that hormone was produced by 47 to 62 -day embryos. Although difficult to determine, the sequential development of the maturation 
process (testosterone secretion, appearance of Leydig cells) seems to follow the same pattern in species with a short gestation. Thus, at the sex gonad differentiation stage (day 12 ), the mouse embryo testis shows $\Delta_{5}$-3 $\beta$-hydroxysteroid dehydrogenase activity (Baillie and Griffiths 1964 ; Scheib and Lombard, 1971), and can synthesize testosterone from progesterone in vitro (Weniger and Zeis, 1972). Very soon afterwards (days $121 / 2$ to 13 ), the Leydig cells can be distinguished by electron microscopy (Scheib, 1970, 1972).

2) While the presence of AFT cannot be denied, we have no data on the route used by the fetal blood testosterone reaching the amniotic cavity. Saunders and Rhodes (1973) proposed the mesonephros as a pathway since it is functional in the fetus before degenerating. However, the primate allantois is little developed, disappearing early in embryogenesis, and there is no direct route to the amniotic cavity from the urogenital sinus before the external genital organs differentiate. Therefore, the amniotic cavity only communicates with the interior of the fetus by buccal or anal route. Fetal testosterone would probably thus follow the digestive pathway to reach the amniotic fluid and the testosterone content in both compartments may be balanced.

Contrary to Resko (1970), we found no fetal sex-related variation in maternal blood testosterone level during gestation, even between days 57 and 75 of gestation, when high testosterone concentrations were found in the umbilical artery blood of male fetuses. On the other hand, that author observed no correlation between peripheral and uterine vein testosteronemia of the mother.

In women, there is no correlation between maternal testosteronemia and fetal sex at week 20 of gestation, when the fetal testis is most active, or even at delivery (Mizuno et al., 1968 ; Rivarola, Forest and Migeon, 1968 ; Saez and Bertrand, 1969 ; Abramovich, 1974 ; Dawood and Saxena, 1977). Maternal testosteronemia therefore cannot be used as a criterion to sex the conceptus.

4th Workshop on « Development and maturation of the reproductive organs and functions 》

Luynes, France, octobre 1978.

Acknowledgments. - The authors are grateful for the helpful suggestions and criticisms of Professor C. Thibault and the encouragement of Professor A. Delmas throughout the study. Thanks are also due to Mrs. Aphaecix, Baret and Carpentier for careful maintenance of the experimental animals. This work was supported by the Délégation Générale de la Recherche Scientifique et Technique (Contract No77-7-0671).

Résumé. 88 fœetus de macaque Crabier (Macaca fascicularis), d'âge précis ont été étudiés, à partir du 37 e jour jusque vers la fin de gestation. La testostérone a été dosée par méthode radioimmunologique dans les plasmas artériel (TPAO) et veineux (TPVO) ombilicaux, dans le liquide amniotique (TLA) ainsi que dans le sang périphérique maternel.

1) Chez les fotus mâles, vers 57 jours, le taux de TPAO est de 3 à $4 \mathrm{ng} / \mathrm{ml}$, puis chute vers 75 jours pour se maintenir entre $0,5 \mathrm{ng} / \mathrm{ml}$ et $1 \mathrm{ng} / \mathrm{ml}$ jusque vers la fin de la gestation. Chez les fœtus femelles, cette teneur demeure aux environs de $1 \mathrm{ng} / \mathrm{ml}$ pendant toute la gestation (fig. 1).

2) Au cours de la deuxième moitié de la gestation, le taux de TPVO est généralement plus faible que celui de TPAO, quel que soit le sexe fœtal (tabl. 1). 
3) Le taux de TLA est nettement plus faible que celui de TPAO ou de TPVO ef en-dessous de la sensibilité du dosage chez la plupart des fœtus femelles. Chez les fœus mâles, sa teneur évolue parallèlement à celle de la TPAO (fig. 2). Le coefficient de corrélation est de $r=0,71$ (fig. 3). L'existence de cette corrélation ef la présence de quantité relativement importantes de TLA chez les foetus mâles, âgés de 37 à 50 jours, permettent de penser que les testicules fœłaux sont susceptibles de secréter la testostérone très tôt et en l'absence de cellules de Leydig reconnaissables.

4) II n'existe aucune relation entre la testostéronémie de la mère et le sexe de son conceptus tout au cours de la gestation (fig. 4).

\section{References}

ABRAMOVICH R. R., ROWE P., 1973. Fœtal plasma testosterone levels at mid-pregnancy and at term : relationship to fotal sex. J. Endocrinol., 56, 621-622.

ABRAMOVICH R. R., 1974. Human sexual differentiation. In ufero influences. J. Obstet. Gynaecol. Brit. Comm., 81, 448-453.

ATTAL J., 1969. Levels of testosterone, androstenedione, estrone and estradiol-17 $\beta$ in the testes of fetal sheep. Endocrinol., 85, 280-289.

BAILLIE A. H., GRIFFITHS K., 1964. 3ß-hydroxysteroid deshydrogenase in the fœial mouse Leydig cell. J. Endocrinol., 31, 63-66.

BELISLE S., FENCL M. M., TULCHINSKY D., 1977. Amniotic fluid testosterone and follicle-stimulating hormone in the determination of fetal sex. Am. J. Obstet. Gynecol., 128, 514-519.

DANG D. C., 1977a. Absence of seasonal variation in the length of the menstrual cycle and the fertility of the crab-eating macaque (Macaca fascicularis) raised under natural daylight ratio. Ann. Biol. anim. Bioch. Biophys., 17, 1-7.

DANG D. C., 1977b. Resumption of menstruation and fertility after caesarian in Macaca fascicularis. Ann. Biol. anim. Bioch. Biophys., 17, 325-329.

DANG D. C., 1978. Sexual differentiation of the external genital organs of the Macaca fascicularis fetus. Ann. Biol. anim. Bioch. Biophys., 18, 681-687.

DANG D. C., FOUQUET J. P., 1979. Differentiation of the fetal gonad of Macaca foscicularis, with special reference to testis. Ann. Biol. anim. Bioch. Biophys., 19, 1197-1209.

DAWOOD M. Y., SAXENA B. B., 1977. Testosterone and dihydrotestosterone in maternal and cord blood and in amniotic fluid. Am. J. Obstet. Gynecol., 129, 37-42.

FOUQUET J. P., DANG D. C., MEUSY-DESSOLLE N., 1978. Functional differentiation of Leydig cells in the testis of the fetal monkey (Macaca fascicularis). Ann. Biol. anim. Bioch. Biophys., 18, 1205-1221.

FRASIER S. D., WEISS B. A., HORTON R., 1974. Amniotic fluid testosterone : implications for the prenatal diagnosis of congenital adrenal hyperplasia. J. Pediatr., 84, 738-741.

GILES H. R., LOX C. D., HEINE M. W., CHRISTIAN C. D., 1974. Intrauterine fetal sex determination by radioimmunoassay of amniotic fluid testosterone. Gynecol. Invest., 5, 317-323.

HUHTANIEMI I., KORENBROT C., LAUTALA P., JAFFE R. B., 1979. Testicular steroidogenesis and its regulation in the primate fetus and newborn. Ann. Biol. anim. Biochem. Biophys., 19, 1327-1338.

JUDD H. L., ROBINSON J. D., YOUNG P. E., JONES C. W., 1976. Amniotic fluid testosterone levels in midpregnancy. Obstet. Gynecol., 48, 690-692.

MAULÉON P., BÉZARD J., TERQUI M., 1977. Very early and transient 17 $\beta$-estradiol secretion by fetal sheep ovary. In vitro study. Ann. Biol. anim. Bioch. Biophys., 17, 399-401.

MEUSY-DESSOLLE N., 1974. Evolution du taux de testostérone plasmatique au cours de la vie fœetale chez le porc domestique (Sus scrofa L.). C. R. Acad. Sci. Paris, Ser. D., 278, 1257-1260.

MEUSY-DESSOLLE N., 1975. Variations quantitatives de la testostérone plasmatique chez le porc mâle, de la naissance à l'âge adulte. C. R. Acad. Sci. Paris, Ser. D., 281, 1875-1878.

MIZUNO M., LOBOTSKY J., LLOYD C. W., KOBAYASHI T., MURASAWA Y., 1968. Plasma androstenedione and testosterone during pregnancy and in the newborn. J. clin. Endocrinol. Metab., 28, $1133-1142$. 
RESKO J. A., 1970. Androgen secretion by the fetal and neonatal rhesus monkey. Endocrinol., 87, 680-687.

RESKO J. A., 1974. Sex steroids in the circulation of the fetal and neonatal rhesus monkey : a comparison between male and female fetuses. In Endocrinologie sexuelle de la période périnatale, Coll. I. N. S. E. R. M. 32, 195-204, Ed. INSERM.

RESKO J. A., MALLEY A., BEGLEY D., HESS D. L., 1973. Radioimmunoassay of testosterone during fetal development of the rhesus monkey. Endocrinology, 93, 156-161.

REYES F. 1., BORODITSKY R. S., WINTER J. S. D., FAIMAN C., 1974. Słudies on human sexual development. II : Fetal and maternal serum gonadotropin and sex steroids concentrations. J. clin. Endocrinol. Metab., 38, 612-617.

RIVAROLA M. A., FOREST M. G., MIGEON C. J., 1968. Testosterone, androstenedione and dehydroepiandrosterone in plasma during pregnancy and delivery : concentration and protein binding. J. clin. Endocrinol. Metab., 28, 34-40.

ROBINSON J. D., JUDD H. L., YOUNG P. E., JONES O. W., YEN S. S., 1977. Amniotic fluid androgens and estrogens in midgestation. J. clin. Endocrinol. Metab., 45, 755-761.

SAEZ J. M., BERTRAND J., 1969. Androgen studies in the fœio-placental unit. Excerpia med. Int. Congr. Ser., 183, 132-141.

SAUNDERS P., RHODES P., 1973. The origin and circulation of the amniotic fluid. 1-18. In FAIRWEATHER D. V. I., ESKES T. K. A., Amniotic fluid : research and clinical application. Excerpta med. Monogr. Ser. 47.

SCHEIB D., 1970. Structure fine des cellules interstitielles du testicule fœtal de la souris blanche C. R. Acad. Sci. Paris, Sér. D., 271, 423-425.

SCHEIB D., 1972. Ultrastructure ef fonction des cellules interstitielles du testicule de la souris : évolution fotale. Ann. Embryol. Morph., 5, 121-133.

SCHEIB D., LOMBARD M. N., 1971. Etude histo-enzymologique de l'activité de la $\Delta_{5}-3 \beta$ hydroxystéroïde déshydrogénase du testicule de souris blanche. Arch. Anat. micro. Morph. exp., 60, 205-218.

VAN WAGENEN G., SIMPSON M. E., 1965. Embryology of the ovary and testis in Homo sapiens and Macaca mulatta. Yale Univ. Press, New-Haven \& London.

YOUNGLAI E. V., 1972. Androgens in human amniofic fluid : relation to sex of the newborn. $J$. Endocrinol., 54, 513-514.

YOUNGLAI E. V., LIN C. C., 1973. Fetal androgen and human chorionic gonadotropin excretion in relation to genetic sex. Am. J. Obstet. Gynecol., 117, 291-292.

ZONDEK T., MANSFIELD M. D., ZONDEK L. H., 1977. Amniotic fluid testosterone and fetal sex determination in the first half of pregnancy. Brit. J. Obstet. Gynaecol., 84, 714-716.

WENIGER J. P., ZEIS A., 1972. Sur la sécrétion précoce de testostérone par le testicule embryonnaire de souris. C. R. Acad. Sci., Paris, Série D, 275, 1431-1433. 